\title{
Violence, Bureaucracy and Intreccio in Brazil
}

\begin{abstract}
For Brazil's 'violence worker' street level bureaucrats, violence is woven into everyday practice. But violent influence flows in multiple directions; from the state to society, within the state and its agencies, from violent actors upon state bureaucrats. Real and potential violence defines the bureaucratic regime of truth, alongside the influence of a self-defined organised crime group. Using ethnographic evidence, I show some of the fissures that are wedged open through violence, and demonstrate the ways that violent uncertainty shapes a need for leverage and spheres of trust. This shows the dissonance between bureaucratic form and bureaucratic rationale, where other violence workers -ontological bureaucrats- have become an everyday part of bureaucratic rationale. What matters is not the relationship between the state and bureaucracy, but the relationship between sovereign power and bureaucracy.
\end{abstract}

\section{Keywords}

Bureaucracy, Violence, Brazil, the State, Organised Crime, Police 


\section{Introduction}

Miguel had just arrived home, stopping his car on the sidewalk to get out and open his garage door. As he did he was approached by two young men. They shot him three times, killing him for his car. Miguel worked in the homicide and missing person police division in one of Brazil's largest cities, which I call Cidade Alta, where I carried out ethnographic research. An affable story teller in the station and on the street, Miguel's killing was one more example of violent pressure on what Lipsky terms the 'street-level bureaucrat' ${ }^{1}$. In Brazil, as much elsewhere, these front line state workers - especially the subset of 'violence workers ${ }^{2}$ - face systemic coercion, through real, assumed and anticipated violence. Such violence is woven into everyday experience, shaping how bureaucracy 'works' at daily tempos.

When it comes to violence in Latin America, there is widespread concern, in explicit or implied ways, with why states don't perform as they might. Whether framed in the foreclosure of incipient democracy, in the shambles of abandoned or crumbling infrastructure, or in high rates of police killings, the states of Latin America seem to fall below the bar of hegemonic normative expectations. But where expectations are little more than aspirational or prescriptive, what gives?

This sense of governance 'failure' or 'insufficiency' is especially apparent in the dissonance between conceptual or de jure -ideal Weberian- and de facto -ontological-, bureaucracy. While ideal types of bureaucracy are wedded to longings for centralised violence, a 'formed' state, and autonomous institutions, supposing the absence of violent counterweights, the empirics of Latin America evoke a much different actually-existing bureaucratic condition. In an era of incipient sovereignties ${ }^{3}$, non-state armed groups ${ }^{4}$ and heightened practices of everyday violence, it is high time to scrutinize the reification of bureaucracy. This means 
reflecting upon where bureaucracy exists in everyday life, who carries it out, and how different bureaucratic forms are enmeshed, or not, with their practices.

To date, little work has productively elucidated the conceptual dissonance between expected bureaucracy and ontological bureaucracy -especially as violence drives a thick wedge between them. Here, I seek to do so. State institutions and their functionaries -police, prosecutors, corrections officers, judges, and many others- pattern their work in response to the mundane but uncertain possibility of violence. While some of this happens in response to plata o plomo -'bullets or bucks'- kinds of selective violence or assassination, workers must more generally find ways to mitigate systemic uncertainty. Most openly recognise how persistent 'ambient' violence -a street robbery, a home invasion- will be lethal if they are identified as state violence workers in the process.

In what follows, I make an incipient effort to trace how systemic violence is intertwined with bureaucracy, and the ways that this matters. What is bureaucracy where crime is so pervasive that the state's deployment of the 'criminal' category is self-incriminating? I use Foucault's idea of a bureaucratic 'regime of truth" ${ }^{5}$-the assumptions and ways of acting in an actually existing bureaucracy- to shed some light on 'violent work' amidst the uncertainty of violence in Cidade Alta. In this city few would argue that bureaucratic form and bureaucratic rationality are well aligned. That they are not is well revealed by evidence that law on the books don't matter, whether in terms of mundane police killings, mundane killings of police or a homicide decline attributed by many to organised crime ${ }^{6}$.

But even these practices have their own bureaucratic hallmarks, showing that street level violence workers, as bureaucrats, well transcend the state. Building on Schneider and 
Schneider's notion of 'intreccio', as the interweaving of Italian state and mafia spheres in a “vast gray area",, I illustrate how bureaucracy and everyday violence have become mixed by sovereign prerogative. I argue that state and non-state violence workers are enmeshed in uncertain but predictable ways, written through by the existence or possibility of violence, in everyday bureaucratic practices, creating distinct systemic effects in the regulation of violence.

This set of reflections is based on a multi-year ethnographic research project carried out Cidade Alta. Over a three year period I accompanied homicide and other detectives in their daily routines. The following complements a series of other interventions ${ }^{8}$ where I more completely address the methodological challenges and nuances surrounding the study of policing, violence and organised crime in Brazil. A caveat: what follows is an enlargement and a deliberate and detailed discussion of a concern that I point to briefly in a recent book ${ }^{9}$.

\section{Bureaucracy De-centred}

Max Weber's concept of bureaucracy, and especially his intertwined ideas of the state and bureaucratic rationality, have become nearly hegemonic. For Weber bureaucratic autonomy and state capacity are intertwined and inseparable ${ }^{10}$. A professional bureaucracy, autonomous and at a distance from political or economic interests and influences, is a capable bureaucracy. Such capability is well reflected in the predictability and reliability of institutional outcomes and of the larger production and consumption of order by the ruled. Such a bureaucracy is coterminous with political legitimacy, where, as Weber sees it, bureaucracy in "public and lawful government" constitutes a particular kind of power that he called "bureaucratic authority". This stands conceptually alongside bureaucracy in "private 
economic domination", in the realm of capitalist practice, to be spoken of, rather, as "bureaucratic "management",

Crucially, Weber's position sees a synergy between bureaucratic form and rationality. The form of bureaucracy, its institutions, agencies, and actors, are closely aligned with bureaucratic rationality -the rules, norms and practices that matter. The latter is shaped by the former and vice versa, in a mutually reinforcing pattern of social and political practice. For Townley this is well illustrated by how state institutions secrete and reproduce bureaucratic rationality by "drawing definitional boundaries, rules, procedures, codes, protocols, and writing the world in formalized terms, that enable [them] to be known, become predictable, and be acted upon. ${ }^{12}$ " Where form and rationality are closely aligned, such rules are largely uncontested, precipitating spheres of order and related practice where punishment in written or paper form is as heavy and internalized as punishment by directly violent means. Put differently, where bureaucratic form and bureaucratic rationality are mutually produced, reinforced and more or less contained, a 'legitimate' is possible.

In Latin America, and elsewhere, such a condition seems distant. Today, a dominant body of scholarship is preoccupied with violence in the region, noting its institutionalised hallmarks and the failure of actually existing bureaucracies to temper patronistic patterns of rule, to usher in a 'deep democracy' or to mitigate violence as a persistent condition ${ }^{13}$. Whether discussed in terms of violent democracy, consensual forms of killing, or how armed groups are now well subsumed within states, debates are turning towards an understanding of the ways that violence, and crisis, are increasingly institutionalised, and, predictable -in spite of expectations for bureaucratic autonomy and legitimacy. As a result, scholars have begun to conceptually situate states as 'weak', 'hybrid', 'negotiated' or 'networked', pointing to the 
routine, sustained or structural condition of the varied violent actors and practices that exist within them ${ }^{14}$.

But if the scholarly departure from some 'ideal' Weberian notion of the state is well underway, an accompanying revision of the idea of bureaucracy has been slower to follow. In political science, leading scholarship now recognizes the ways that bureaucratic disorder is maintained in favour of larger political interests ${ }^{15}$. We know, too, that bureaucracies can take on a life of their own ${ }^{16}$. Part of the question is what defines that life? There is some momentum to answer this question, especially following a resurgence of interest in the state from ethnographers and political economic analyses ${ }^{17}$. An incipient discussion has formed around the practice of bureaucracy in and upon the Global South ${ }^{18}$. This is especially emergent from qualitative scholars, with their focus on situated realities and rooted theorisations and as part of a larger conceptual relocation of the state within, or in spite of, Foucauldian frameworks ${ }^{19}$. Efforts to give some lived form to 'stateness' in diffuse governmentality and locally situated power can be advanced by reflecting on vital works about everyday legality ${ }^{20}$ and legal pluralism ${ }^{21}$. This discussion and evidence points toward lived realities about what 'law' and 'justice' really means in everyday conditions -in spite of the state -and especially in an era of neo-liberal securitisation ${ }^{22}$. As an epistemic lens and mode of critical interrogation ethnography is ideally suited for considering such questions of everyday assemblages that constitute and uphold political power ${ }^{23}$.

One way that scholars have engaged with this problem, but using different terminologies, is through the idea of informality ${ }^{24}$. The systemic practice of unenforced illegality, sometimes meekly termed 'impunity', across spheres as diverse as housing and security is more relevant than deploying tautological and normative state-centric categories about the 'illegal' or the 
criminal. 'Illegality' is relevant not because it defines what is not legal, because it is mundane and politically accepted, being subject to other kinds of unwritten rules and patterns of negotiation that fasten together categories that are often seen as normatively distinct. These rules and patterns of control are not necessarily less meaningful or predictable than a legitimate law on the books, however. Not noteworthy under a larger administration of political authority, informal patterns and logics of social order have become impossible to disaggregate from centrally reproduced patterns of stability and convention.

Scholars have also recognized that the bureaucrat herself is important as a site of analytical interrogation. A return to Lipsky's intervention of the 'street level bureaucrat', the public facing state worker who ultimately delivers public policy as a negotiator and a subject of discretionary decision making, has grounded these reflections. This recognition of 'street level' negotiation is crucial because it opens conceptual space for thinking about how influence flows in multiple directions, such as from a) the bureaucrat to citizens, social groups or businesses; b) within different constituencies, agencies or social spheres within the state, and/or; c) from citizens, social groups or businesses upon the state. How these patterns of influence, which may be coercive, compassionate or some combination of, converge in the empirical practices of street level bureaucrat work. How this matters in terms of violence -as a sovereign prerogative of order-making ${ }^{25}$ - should be the source of acute scholarly concern and debate. As Weeden and others note, after all, such questions of legitimacy are centrally about social control and racial or other dominance ${ }^{26}$.

Such an epistemic lens matters, in part, because of how front line bureaucrats would use their discretion. Do they bend over backwards to please business? Do they have implied ties with lobbyists? Are they terrified of being assassinated? What do they use for everyday leverage? 
Each open question suggest different systemic and historical conditions related in everyday patterns of political practice. Approached with analytical sensitivity, such practices denote the sorts of hierarchical relationships and patterns of social deference that guide bureaucratic outcomes. In Latin America, a modest body of research follows this analytical vein; how 'weak' bureaucracies and their bureaucrats make do in spite of a series of structural constraints. This body of work routinely points out that bureaucrats require leverage, external or internal, to achieve stated or formal goals. These goals may be political, regulatory or about patron-client relations. All surround the way that law is practiced and applied, empirically. How they are defined and seen as ideal -strived for- matters a great deal.

The need for street-level bureaucrats to find leverage is not exceptional. It is a persistent condition. Leverage allows for bureaucracies to 'function' -that is, to meet stated regulatory or legal benchmarks as they exist on the books- where there is a yawning gap between expectations and everyday conditions. This means that bureaucrats often have patterned and predictable relationships with external actors, internal colleagues or political clients. Without such leverage, nothing would work at all. Amengual for example, has argued that Argentine labour regulators must lean on civil society organisations, including unions, to enforce labour regulations $^{27}$. Similarly, Coslovsky finds that Brazilian public defenders are deeply entangled with other social entities, whom they mobilise when needed ${ }^{28}$. At the same time, Latin America has seen an outgrowth in 'private' forms of regulation and bureaucracy, in keeping with neoliberal logics ${ }^{29}$. These sometimes work in parallel, but often are deeply enmeshed in the political economy of rules and order.

A touch of Foucault may help to advance conceptual clarity about how these questions fit together. Foucault argues that what is right and normal is unquestioned constitutes a 'regime 
of truth'. A regime of truth is the paradigm of political value, constituted by techniques, procedures and boundaries, through and in the defense of which, a practice of power is upheld. Such a regime is situated, and can be well elucidated by examining the paradigmatic assumptions that surround that work of street level bureaucrats. This is, in part, an epistemological question that needs to make sense of the everyday practices, constraints and unexceptional ways of being for state workers.

In what follows, I turn a focus to the bureaucratic 'regime of truth' for Cidade Alta's street level violence workers. These bureaucrats exist within a regime where the relationship between organized crime, self-defined criminals and drug traffickers, and state bureaucrats is mundane, unquestioned and a source of chronic negotiation. Much work has laid the foundation for such scholarly heavy lifting by showing the ways that such 'non-state armed groups', -especially urban ones- have been made normal ${ }^{30}$. Arias argues, for example, that a kind of 'network' exists between Rio's drug traffickers, state bureaucrats and the practices of formal democracy ${ }^{31}$. Working on the Italian mafias, Schneider and Schneider evoke this political-economy of truth similarly well. They argue that the historical relationships between state and mafia constitute an intreccio - an 'interweaving of spheres'- where it has been made impossible to disentangle the larger practice of power and order from the intertwined practices of state's bureaucracy and the bureaucratic practices of the Sicilian mafia ${ }^{32}$. This is not just about tit for tat reciprocity. A space of intreccio is about systemic forms of exchange and interconnectedness. Conceptually, such a lens means being open to decentering the idea and practice of 'security bureaucracy' from the state, and to think about how a bureaucratic regime of truth, in a context of violence, may work as an assemblage of violent actors, operating in a mutually understood but tenuous set of negotiations and relationships -real or implied. In other words, to be sensitive to the ways that violence is woven into the 
bureaucratic fabric, leading to ongoing patterns of mending, tearing, mistrust and cobbling together.

\section{Everyday Violence and Bureaucracy}

Throughout Latin America, as in many places, violence surrounds and engulfs society, politics and institutions. It has become indistinguishable from the lived experience, where 'everyday violence', not just as a structural condition but as mundane encounter with direct violence, is as unexceptional as it is tremendously important as a paradigm of pressures, incentives and constraints. It is well imbued in the ways that bureaucrats make decisions from one moment to the next.

One afternoon a group of homicide detectives and I were sitting in the room near the front entrance to the central Civil Police building in downtown Cidade Alta. At some point, a man walks in, wanting to speak to police. Most of the detectives walk away, or direct him next door, believing that this man's concern doesn't relate to a homicide. The man walks next door to the central foyer of the headquarters. But soon he returns, having not found anyone to help him there either. He's concerned: There are some shady characters down and around the corner, he says. They look suspicious, as though waiting for someone or something to happen. "I just thought I should tell someone," he says to the detectives. His words fall on disinclined ears. This man is a busybody that should "mind his own business", according to detectives.

The detectives chatter, and characterize the man -who has since left- as a nuisance. "What does he care", says one of them. After much grumbling, the group decides they should have a look, in spite of the bother. Eager, but certainly naïve, I decide to join them, trailing behind. 
The location where the men were reported to be is roughly a block away, on a diagonal transect from where the detectives leave the station. They decide to split up. One group of two goes straight and will turn right. The other three, and me, head right and will turn left. We'll converge, they surmise, on whatever might be there. The mood is relatively upbeat, if bothered by the man's busybody demand to shake a leg.

All of that changes in an instant, as we turn left around the corner. Guns come out. In view, a dark skinned man stands behind a shut newspaper kiosk, peeking around it the opposite direction from us. He is in his very late teens or early twenties, with a tapered crew cut, a hoody and long dark shorts, with new looking sneakers. This is, for police, the picture of the criminal type that motivates policing -the bandido. Across the street is another man, wearing roughly the same type of clothing and appearing equally out of place; 'shifty', as the man who reported them had described. They seem to be focused on the same thing. I follow the three detectives, all of whom are well advanced in age, are not particularly agile and who often enjoy their Marlboros -or similar. As we walk toward the man standing behind the kiosk, the detectives become agitated. All three have now draw their guns, beginning to walk in a deliberate fashion, arms and gun raised and pointed at the man. They haven't yet spoken a word though.

Then it strikes me. What am I doing? What if the man pulls out a gun - as routinely happens in such confrontations? I'm walking directly behind the three detectives, who have now come within forty feet of the kiosk. I duck behind a grand but grimy urban tree, of the kind that's roots are littered with fecal matter and other burned out refuse, its crown having provided shelter of many kinds in the city. One of the three detectives shouts policia! The man turns to face, startled. From the other street, to our left, a detective bursts into view, running toward 
him. The man runs, splitting four lanes of moving traffic. He jumps an abutment and sprints down an off ramp, running in and out between the moving cars coming toward him. The detective gives chase, leaving nothing in reserve. They disappear from view as the man darts across a terribly fast highway artery running North-South through the city. Either he's done something, he is terrified for his life, or, both.

The other man vanished. No one saw where he went. It didn't seem to matter. The remaining detectives are left boiling with an unfulfilled spike in their adrenaline. It was all over almost as quickly as it began. The chasing detective returned, exhausted and defeated, his gun back in his plain-clothes jeans. There was no radioing to others in the case, no jumping in the squad car. No incident filed. No pen would ever touch paper about this -except mine. No waiting to see if the something that the men may have been waiting for would appear anyway. The two men were gone, vanished back into the urban fabric. And I understand why the busybody is a bothersome nuisance: why stick your neck out? Just as easily as nothing happened this time, one of the men, a police officer, or me -the foreign idiot-, could have been left bleeding profusely or dead.

It strikes me that the work of being a police officer in this city is largely about mitigating uncertainty. That street level bureaucrats will regularly choose to avoid circumstances of violence shouldn't be surprising. I've written extensively about how it has become commonplace for police officers to disguise themselves as something -anything- different from being a violence worker. This includes by not telling acquaintances or family about their profession. More colloquially, this worry is subsumed in the well-worn trope that police must "dry their uniform behind the refrigerator". Not only so, they are forced into everyday mediations with those that might do them harm - some of whom are also state bureaucrats. 
The uncertainty of violence, and a generalised lack of trust in state bureaucracy as an agglomeration, means that fragments or groupings of street level bureaucrats start to emerge to pursue their own interests. These are commonly collected under a particular patron, such as a delegado ${ }^{33}$ or a mid-level Military Police officer, under whose association larger plans or schemes may be carried out.

\section{Whose Street Level?}

The ways that violence and its effects have become normal sometimes defies belief, in this city and elsewhere. Denyer Willis describes the ways that residents of a Rio de Janeiro favela speak of the entry of the police' armoured and tank-like caveirão - 'big skull'- during preOlympic pacification of their neighbourhood in $2009^{34}$. Residents told tales of the fluidity of the armed actors involved -paramilitaries, drug traffickers, police-, showing little interest in distinguishing them as useful categories. Others spoke of the times that police had rented out the 'big skull' to the gangs so that they could retake neighbourhoods and new markets from other drug trafficking groups. Rumour and innuendo, leading to glorified stories, most would assume. That police would ever rent their own equipment, like an armour personnel carrier, seems a fable of impossible nonsense.

Years later, in June 2017, in what they termed 'Operation Calabar', Rio de Janeiro prosecutors arrested at least 86 police officers and 23 suspected criminals for their involvement in a widespread system of graft that included renting the big skull to drug traffickers $^{35}$. Calabar came on the heels of another investigation, spurred by a newspaper publications about a series of handheld videos and audio recordings of 'non-police' voices inside the big skull during a police operation. According to this investigation, police had charged members of a particular drug trafficking group 1 million Reais (\$314,475 USD) to 
enter and use the big skull to drive in to the territory of a rival group, taking it from them ${ }^{36}$.

For citizens, the categories of 'police' and 'criminal' are highly porous. The same is true even for violence workers themselves. Who one can trust is always a fluid and iterative question. In such a circumstance, there is a great deal of animosity and suspicion among violence workers themselves. Police themselves don't know who is a 'criminal', who is 'good' police officer and who is 'criminal' and police officer at the same time -or even that such synergies are so neat. The means that each of these categories are subverted to larger concerns and priorities. Where it has become commonplace for police to threaten or kill other police, members of the judiciary and citizens, or for the opposite to occur, there are enduring and systemic effects. Mistrust defines bureaucracies where supposedly complementary agencies have come to see their role and efforts as violently antagonistic with the work of others. This results in the obstruction of information, evidence and much else. But, also, it leads to violent defences of symbolic territory, jurisdiction and 'truth'. Law on the books is a clear casualty, though much else suffers by consequence.

Still, real or assumed violence is not the end point. These bureaucrats find everyday means of making do, such as by attempting to remedy, tediously, for the absence of trust, information and resources within the state itself. Consider an example from my ethnographic fieldwork, about the fracturing of trust, and the composition of modes of transcendence by bureaucrats trying to get things done:

We sat in a two story government walk-up, down the street from the court house. The entrance of the innocuous looking concrete building was guarded by a single metal detector that most people routinely stepped around, and an affable private security guard armed with a 
feeble looking six-shooter. Upstairs, in a room segregated with a series of temporary dividers I listened as the prosecutor I was interviewing told me a story about a recent case. They had finished a case to be proud of, a long and arduous investigation of a suspected organized crime figure in the city. He was eager to show me all sorts of documents, data and files surrounding the case and others like it.

This case entailed a broad scope of measures, ranging from tracking bank transfers and deposits between members of the group, undertaking judicially authorized wiretaps of telephone calls, drawing on interviews with former associates and compiling reams of background material, including everything from past criminal histories and networked connections to other convicted members of the organized crime group in question. This investigation, if any, had been done by the book. Months of diligence was about to pay off. The next day the group of investigators and a small, insular, and trusted group of police detectives of the Civil Police would show up at the man's house, break down the door in a grand commotion and take him away to be charged, convicted and sent to prison for a long time. Early the day before, though, it was necessary to inform the Military Police ${ }^{37}$ who would send a heavily armed backup squad in case things got ugly -as they are prone to do.

Late on the eve of the arrest, the investigator received a call on his mobile phone. The suspect was dead. As night fell, armed and masked men appeared on his stoop on the outskirts of the city, riddling him with bullets. The investigator knew exactly what had happened. It was just as he feared. "They thought he had killed a police officer", he told me. "That was one of the rumors about him. This was their last chance to get revenge." It was true, in a way. It was their last chance to get revenge. Had the man been arrested, he would have been sent to a prison system that is controlled in its near entirety by his organization. For the Military Police 
officers that the prosecutor suspected had carried out the killing, prison was not punishment or suffering enough. He'd be having a barbeque on the weekend with his pals, in one of the more than 150 prisons in the state.

For these other police, revenge was the only way to fulfill their notion of justice. And it came at the expense of diligence, investigation and the procedures of the formal justice bureaucracy. There was virtually no chance the men -officers in the same bureaucracyresponsible for this killing would be found or held to account in any meaningful way, this same practice of extrajudicial executions, especially of black life, having a long and well institutionalized history in Brazil ${ }^{38}$. This case, it seemed, was perfectly symptomatic of what some have enigmatically called the 'unrule of law'39.

All else aside, this case strikes me as normal. The way in which the prosecutor explained the story; it was a chronicle foretold. Certain practices are expected from certain groups and agencies, trust is fragmented into small and predictable social groupings, the rules on the books sit dramatically far from the practices, realities and constraints of the street. The hallmarks of a systematic problem are written within the story of one extrajudicial killing. Clearest of all, the prosecutor's diligent construction of a defensible case -if it indeed happened as he related- is the exception that defines the norm; a thorough effort predictability disarticulated by the way things actually work.

\section{Epistemic Matters: Privilege and Leverage}

Street level violence workers may all be a part of the same bureaucratic form, but they do not have the same bureaucratic rationale -especially when it comes to their mandates and immediate suppositions about violence. For example, a clear paradox exists between the de 
jure and de facto objectives of some police agencies versus others. One acute example is between homicide detectives, who are entrusted with mitigating violence within a longer arc and distant horizon of justice. In a city where police kill hundreds per year, and homicides happen in the thousands, the everyday bureaucratic terrain for detectives is highly complex.

In theory, any effort to resolve a homicide or a police killing must place emphasis on the judiciousness of investigation, the rigorous collection of data and an extensive search for evidence, towards the construction of a case that can be tried by jury. For homicide detectives, who are entrusted with a mandate to limit the indiscriminate use of violence in the city, this means thinking clearly about motives, conditions and much else.

Beat cops, who in Brazil are the Military Police, serve in a different mode. They are emboldened by direct violence, year on year producing a body count in the hundreds. In the country, between January 2015 and December 2016, Brazilian police killed 5, 896 people $76 \%$ of whom where black ${ }^{40}$. The Military Police are, too, a police agency -one of the only in the world- that has its own prison - though typically for those who kill on the job ${ }^{41}$.

In Cidade Alta, as all Brazilian cities, the latter trumps the former in numbers, political capital and resources. And yet, the former is responsible for investigating and arresting the egregious direct violence of the latter. The conditions of this asymmetry draw out directly in the everyday negotiations of both, and especially as relative to the other. On the one hand, how do we continue to repress criminals violently without being arrested by those investigating our violence? And on the other, how do we ensure that violent death happens less often -and that when police kill, we know when they are faking evidence, how they tell half-truths and when they have simply executed someone? That this is a daily negotiation, 
happening around multiple cases every day, on average, means that patterns of routinization are established, with corresponding categories, assumptions and 'hunches'. In other words, homicide detectives, as military police, seen all of this within a framework of "normal crime”, where they “... [gain] knowledge of the typical manner in which offenses are committed, the social characteristics of the persons who regularly commit them, the features of the settings in which they occur, the types of victims often involved, and the like."42

One case from my ethnographic research is particularly illustrative. While I was accompanying homicide detectives, the city suffered a violent crisis where organized crime and police began to attack and kill each other at a quotidian pace. This acute uncertainty was reconfiguring some of the ways that homicide detectives approached their cases. Even as they often, usually, sided in defense of police shootings of citizens they were also occasionally confronted with egregious or audacious violations. In these cases, they would find ways to right an assumed wrong, by relying on their discretion or by seeking extra evidence, more witnesses or other possibilities. This sometimes played out revealing ways, as I recall from my fieldnotes ${ }^{43}$ :

In the midst of this new surge in violence, I'd been trying to keep on top of the news. Every day there were reports of police being killed. It was hard to keep up, and the media never even managed all that well. Before going to the precinct for a shift I'd read through the latest stories by Googling 'policial morto - 'dead police’ for this city. There were new hits everyday. And those were just the dead police that made the news, not the injured or forgotten ones. 
On this particular night the news reports were talking about more buses being burned, more multiple homicides in the last few days, and a marked spike in homicides overall. Nine homicides, including the multiple killing -chacina- yesterday they said. Police authorities are now saying that they recognize there is a connection between police killings and an organized crime group. They have some evidence, gleaned from wiretaps of group members that they'll 'sentar o pau' - 'will make them feel the pain'- a phrase apparently coming from the mouth of a group leader in a well known district. As I walk to the homicide department I can't avoid the feeling that I am about as close to the middle of this as anyone.

Three blocks from the station I see three or four new Toyota Highlanders fly by on the street, with lights flashing and sirens blaring. Something big was probably happening, I thought. Arriving at the station, I saw a couple of police from a notorious unit standing sentry, gruff as they are with stern statures and dark hats. The Civil Police officer at the reception gave me a tough time about giving me my pass. I didn't know him, which was abnormal by now. He was resistant to me being there, maybe because he didn't know me, the city was full of unanswered questions and probably because the place was crawling with these guys. Eventually I convinced him to call upstairs to ask if I had permission to go up. He did, and they said yes. He passed me my swipe card, begrudgingly.

I walked up the four flights of stairs that wind up through the inside of this old station. As I stepped out of the stairwell there was a cloud of troops -probably between twelve and fifteen. Among them was a man in handcuffs. One troop was holding two long and slender bricks of some kind of drug - that I later learned was 1.5 kilos of marijuana. I said good evening to all and walked past into the office. A mix of detectives were there, most still getting off of the day shift. One or two had arrived for the night shift. Two detectives were waiting for more 
information on a case that had happened earlier in the day. The rest of their team was still in the field, dealing with the shooting of a police officer. The troops were heating up outside the door and attention was turning that way. No one yet knew why there was a cloud of police outside the door. No message had arrived on the intranet about anything involving this unit and there was no word of a resistência (police shooting) -which was almost always why they showed up. "They're deciding what they're going to say," said one detective. "How they are going to walk us through the case."

The reason became clear soon enough. Word arrived from upstairs that these troops had been told to bring a case to homicide - even through there was no one dead. Someone important didn't want them taking this case to the organized crime or drug units, both of which, police always say, are thoroughly crooked. Homicide had a reputation for being more reliable and by the book. They had arrested cops from this same unit before, after all.

As the troops came in with the suspect, many of the detectives started jumping all over him, interrogating him about what happened. One or two were particularly forceful, screaming in his face "I'm going to fuck you. I'm going to hang you up. I'm going to fuck your wife, and then your mom if you don't tell me the truth." But after awhile, these same police realized that the story they'd been told by the guys from the street unit actually wasn't that clear. One of the detectives went to his superior to tell him that there were big gaps in the official story. And it was too perfect. It just didn't make sense. The troops said that the prisoner was a member of the organized crime group and that he knew all sorts of things about what had gone down in recent months with police assassinations. They had stumbled across him while patrolling. And after stopping him on the street, they found drugs. He then confessed to being 
a member and to knowing about a meeting when a 'salve' - a message from the prison to all affiliates - was made that called for police to be assassinated.

The suspect, however, had a very different story. According to him, he was picked up by plainclothes police, whom he thought were Civil Police detectives. These police approached him about a debt he owed to the organisation for two machine guns that he'd lost. They asked him about being cobrado (persecuted) with his life for having lost the guns by a member named 'Duque'. He told them he knew nothing of the story, that he was now living under a different alias and hadn't had a single interaction with the organization since he had fled prison in 2008. Initially, he'd had trouble with a powerful member whose girlfriend he had messed around with. These first police had told him that they would "throw him to the police to be killed" unless he could give some information. They'd told him "you'll take these bricks (of marijuana), say they are yours, and you'll take the charge so you don't make us look bad." If you change your story, they had said, we'll kill your wife and daughter.

The yawning gap between these two stories-one simple and logical, the other complex and nuanced wherein a suspect is unruffled about the police accosting him about an unpaid debt to a criminal organization-raised doubt and suspicion among the police detectives. At least one of them very significant: What was the suspect's motive to rat on the organisation, especially knowing that he would be back in their midst in the prison in a matter of days? But the suspect was much less worried about the organisation than he was about this police unit. He didn't want to say everything on paper, or to be recorded. The street unit would be able to read everything, and, he didn't trust that a videotaped statement wouldn't end up in their hands either. Detectives had already prepared the video camera but he steadfastly refused. 
But the detective found a novel way to get the suspect's story out. The suspect had mentioned knowing about a particular group of murders of women that this unit had carried out years prior. And the suspect knew exactly which police officer had pulled the trigger.

The detective convinced him to put down most of his version of the story with a novel bit of leverage: me. The detective wanted use me as 'witness' of his statement. This "Canadian sociologist" would verify and serve as a guarantee against any retaliation, he explained. He could feel good about this because I was there, formally, and the guys from the unit would also know that. The suspect agreed to write his statement of that night's events without details that undermined the unit's story. He would approve it, and he would not be prosecuted for everything that the unit was charging he did, but he could stay the night in the station's jail, where he would be safe. In exchange he would give up everything he knew about the other incident. In that testimony he could also share everything about what happened that night. This statement would not be available to the unit, particularly if he chose to give that statement as a confidential witness.

After the statement was finished and the other detectives took the man away, I asked the detective about the circumstances. Was he a member, after all? Were the drugs his? He's definitely a member, he told me. "He is. Maybe he isn't all that involved anymore, but he is. The smart ones don't carry guns." The drugs were harder to know. "It's difficult," he said, “But I think so." He wasn't worried too much about whether the troops were fucking with this guy. But he was interested in how this case could help solve the other incident. He spoke about the need to be serious about not letting anyone -police or the organisation- "kill 
innocent people", as they did in that incident two years prior. A different detective told the arrested man more:

"In this report the statement is just basic. They'll have access to this report. Tomorrow at a different investigation unit they'll take everything that you've said here and everything else that you know about the killings years ago."

A bit later, the police from the other unit came in to talk about how things progressed with the suspect. A conversation ensued about the violent feud between the organisation and police, and the degree of instability pervading the city as a whole-but for police in particular. "When he told us about the salve where they decided to kill police, I wanted to wring his neck," said an officer from the unit.

In the homicide division they had been investigating all of the police killings since they started to come in big numbers. More than anyone they were seeing first hand the ways that police had been picked off. The detective recalled one of these in a conversation with a police officer from the unit. "It is all on film. The security camera shows the police guy getting shot, twice. You can see everything. Him stumbling (holds his arms out and wavering). The bandido walks up, holds his head and... (feigns holding a gun, pulling the trigger repeatedly)."

"For me, a police officer is a police officer, " said an officer from the unit, lamentingly. "From top to bottom. If one dies we all have to back him up. If not, they will eat us alive." 
And yet both the detective and I knew something that the officer did not. Weeks prior a detective from this homicide group had had a group of these officers arrested for killing a member of the organisation.

I was surprised when the detective brought it up later in a conversation with the officers. "My close friend was the one that had your co-workers arrested. But he kept a few of them out. There were a whole bunch that stayed behind at the crime scene. Internal affairs wanted all of them. He argued that they weren't involved." The officer stood and listened, not showing obvious reaction, almost as though he already knew how and why that case went down the way it did.

Just then the phone rang. A police officer typing a report on a desktop computer picked it up. Another resistência, he said. Police killed a bandido on the South Side. "One less", said the detective. "While on the job?" asked the unit officer. "Goooood".

Acts of violence, the threat of violence and the spectre of violence course through this case. In the background, assassinated police become a justification for even more violent and racialized policing. For the supposed organised crime member in the foreground, there is the possibility of violence against family. Encircling the homicide detectives is the uncertainty of determining when violence did happen, who was involved, and what the likelihood of violence is if they make one decision or another. All of this is decidedly intertwined, enmeshed in various bureaucratic asymmetries, shady epistemes, fissures of mistrust and paradoxes about who is on whose side, and what kind of violence -and against whommatters over all. If homicide detectives take the word of an admitted (former?) organised crime member, and choose to finger other police for violence, they are seen, by those 
powerful and violent police as directly implicated in the ongoing assassinations of their colleagues. Such a reputation that could lead to more extrajudicial violence against these police themselves - a fact that they know and seek to mediate.

Much of this story is about fractures that exist within the state, and especially within a bureaucratic system believed to be tasked with controlling and mitigating violence. Who can be trusted, to what end and why are all deeply unstable questions. A notion of justice is almost obliterated in the midst of pragmatism, a gathering storm cloud of violence and antagonism between two different bodies of street level bureaucrats. And yet, the detective seeks to remedy that asymmetry with a particular piece of power and leverage: a foreign and white male researcher that can serve as a form of insurance, a co-signor of his decision, toward some vague and distant possibility of justice that nonetheless requires overlooking a series of short term criminal acts and situated injustices.

\section{Concluding Thoughts}

Who is a street level bureaucrat? Who is a violence worker? And on behalf of whom? Dal Bo, Dal Bo and Di Tella argue, for example, that the dualism of plata o plomo-bullets or bucks- shapes bureaucratic outcomes ${ }^{44}$. The problem is, where bullets and bucks are used regularly to put pressure on street level bureaucrats, they are often already a systemic problem, a legitimate - uncontestable- form of coercion. There is no appealing to a higher order for assistance. 'Death or drug money' are already a part of the maintenance of order, of a regime of truth. They are systemically part of an intreccio at the centre of bureaucratic practice. 
Charles Tilly famously argued that states are protection rackets, whose legitimate position has been made possible by violent superiority ${ }^{45}$. With their sword and shielded dualism of threat and safety, taxation and security, states act with the same logics of extortion as organized crime. Under this frame bureaucracy is the empirical mechanism of extortion, whether seen as existing to positive or negative ends. And where bureaucratic form comes close to aligning with bureaucratic rationality, the nature of such extortion becomes routinely assumed -rarely questioned or believed unjust. Conceptually, states are organised crime. Empirically, what is the difference between the state and organised crime, especially where people have come to trust organised crime more than the state?

Two things can be added. First, under such a conceptual understanding, practices of bureaucracy need not be confined to particular bureaucratic forms. 'The state' is an undefined container of organisations that happen to centralise bureaucratic practices, in some parts of the world. In these places, such a condition has been achieved over decades, centuries of institutional evolution and legal praxis. But this bureaucratic configuration is not the only possibility; nor necessaritly ome kind of 'best practice' to be strived for. To push for this end, is to overlook how inequitable the experience with the state is, and how people have adapted as a result. Moreover, it overlooks how violence transcends and coerces those working within, exposing distinct fissures. Second, the central and bureaucratic administration of justice by a state, to maintain order and mitigate threats, does not hold in many parts of the world today. Within the cartographic boundaries of states, many new sources of order have assumed governing characteristics, taking on bureaucratic practices in the relative absence or insufficiency of bureaucracy-as-it-exists. And while these different patterns of violent order co-exist, they are also mutually produced and reinforcing. They have been for decades. Their mechanisms of order maintenance reproduce the fluid relationships that follow people, 
money, agency porosity and much else. Here, together, they may serve as a de facto bureaucracy in spite of bureaucratic form. The more or less predictable rationale about the forms of violence and rules that can, and cannot, be broken are the regime of truth. Such a bureaucratic configuration does not fit within the state as a container. It transcends it - just as sovereignty does. What matters is not the relationship between the state and bureaucracy, but the relationship between sovereignty and bureaucracy. Of the ways that violence can be made normal to the interior workings of the state, reorienting the logics of everyday bureaucracy.

To these bureaucrats, real and potential violence have become unexceptional as a coercive force. Seen this way, the maintenance of order through a set of assumed rules that transcend the state, refracted through the asymmetries and fractures within the state itself, bring into relief novel ways of thinking about the normative categories ascribed to the state. The 'criminal', the 'corrupt' or, even, 'rights', are categories that matter where there is little dissonance between bureaucratic form, within the state, and bureaucratic rationality, of its practice. In a society where there is much dissonance, those who exercise sovereign power can do so in spite of the state, while commonplace 'citizens' are subject to bureaucracy and democracy. The asymmetry between the state and sovereignty itself becomes a way to enforce inequitable order, in a 'democracy', with the state's bureaucratic form acting as enforcer. This means that we must advance a different understanding of what bureaucracy is, who it serves and through whom it is deployed. An analysis of street level 'violence workers', amidst everyday violence, shows how this matters. 


\section{Bibiolography}

Alves, J. A. "Neither Humans nor Rights: Some Notes on the Double Negation of Black Life in Brazil." Journal of Black Studies 45, no. 2 (2014): 143-162.

Amengual, M.."Complementary labor regulation: The uncoordinated combination of state and private regulators in the Dominican Republic". World Development, 38 no. 3 (2010): 405-414. doi:10.1016/j.worlddev.2009.09.007

Amengual, M. "Pathways to enforcement: Labor inspectors leveraging linkages with society in Argentina”. ILR Review, 67 no. 1 (2014): 3-33. doi:10.1177/001979391406700101

Amengual, M. (2015). Politicized enforcement in Argentina: Labor and environmental regulation. Cambridge: Cambridge University Press, 2015.

Anand, Nikhil. "Leaky states: Water audits, ignorance, and the politics of infrastructure." Public Culture 27, 2 no. 76 (2015): 305-330. doi: $10.1215 / 08992363-2841880$

Arias, E.D. Criminal Enterprises and Governance in Latin America and the Caribbean. Cambridge: Cambridge University Press, 2017.

Arias, E.D. Drugs and Democracy in Rio de Janeiro: Trafficking, Social Networks and Public Security. Chapel Hill, NC: University of North Carolina Press, 2006.

Arias, E.D. and Goldstien, D. Violent Democracies in Latin America. Durham: Duke University Press, 2010.

Auyero, J. Patients of the state: The politics of waiting in Argentina. Duke University Press, 2012.

Barnes, N. "Criminal politics: An integrated approach to the study of organized crime, politics, and violence." Perspectives on Politics 15, no. 4 (2017): 967-987. 
Biderman, C., De Lima, R.S, Pinho De Mello, J. M., \& Schneider, A. Pax monopolista and crime: the case of the emergence of the Primeiro Comando da Capital in São Paulo. Brasília: CAF Working Paper N²014/03 07/15/2014, 2014.

Biondi, Karina. Sharing this Walk: An Ethnography of Prison Life and the PCC in Brazil. UNC Press Books, 2016.

Bueno, S. and G. Denyer Willis. "The Exceptional Prison” (under review).

Brinks, D. The Judicial Response to Police Violence in Latin America: Inequality and the Rule of Law. Cambridge: Cambridge University Press, 2007.

Brunnegger, Sandra, and Karen Ann Faulk, eds. A Sense of Justice: Legal Knowledge and Lived Experience in Latin America. Palo Alto: Stanford University Press, 2016.

Centeno, M.A., 2002. Blood and Debt: War and the Nation-state in Latin America. Philadelphia: Penn State Press.

Chatterjee, Moyukh. "The impunity effect: Majoritarian rule, everyday legality, and state formation in India." American Ethnologist 44, no. 1(2017): 118-130. Doi: 10.1111/amet.12430

Coslovsky, S. V. "Flying under the radar? The state and the enforcement of labour laws in Brazil”. Oxford Development Studies, 42 no. 2 (2014).: 190-216.doi: $10.1080 / 13600818.2013 .875135$

Coslovsky, S. V. "Beyond Bureaucracy: How Prosecutors and Public Defenders Enforce Urban Planning Laws in São Paulo, Brazil”. International Journal of Urban and Regional Research, 39 no. 6 (2015): 1103-1119. doi: 10.1111/1468-2427.12330

Dal Bó, E., Dal Bó, P. and Di Tella, R. (2006). “"Plata o Plomo?”: Bribe and Punishment in a Theory of Political Influence'. American Political Science Review, 1, 41-53. Doi: $10.1017 / \mathrm{S} 0003055406061995$ 
Davis, D. E. "Non-State Armed Actors, New Imagined Communities and Shifting Patterns of Sovereignty and Insecurity in the Modern World". Contemporary Security Policy, 30 no. 2 (2009): 221-245. doi: 10.1080/13523260903059757

Denyer Willis, Graham. (forthcoming). The Potter's Field. Contemporary Studies in Society and History.

Denyer Willis, Graham. (2017). Before the Body Count: Homicide Statistics and Everyday Security in Latin America. Journal of Latin American Studies, 49, 29-54.doi: $10.1017 / \mathrm{S} 0022216 \mathrm{X} 16000407$

Denyer Willis, G. The Killing Consensus: Police, Organised Crime and the Regulation of Life and Death in Urban Brazil. Oakland: University of California Press, 2015.

Denyer Willis, Graham. (2014). Antagonistic Authorities and the Civil Police in São Paulo, Brazil. Latin American Research Review, 49(1), 3-22. 10.1353/lar.2014.0016

Denyer Willis, Laurie. "The Salvific Sensorium: Pentecostal Life in Rio de Janeiro's Suburbios”. PhD Diss. McGill University, 2017.

Dias, C.C.N. PCC-Hegemonia Nas Prisões e Monopólio da Violência. São Paulo: Saraiva, 2013.

Estadão Conteudo. 2017. "Calabar: mais de 60 policiais são presos em operação contra corrupção R7. April 30. http://noticias.r7.com/rio-de-janeiro/calabar-mais-de-60-policiais-São-presos-emoperacao-contra-corrupcao-30062017

Fantti, Bruna. 2017. Policia cobrava propina de R \$500 mil e R \$1 milhão para uso de chaveirão. O Dia, June 7. http://odia.ig.com.br/rio-de-janeiro/2017-06-07/policiacobrava-propina-de-r-500-mil-ao-mes-e-r-1-milhao-para-uso-de-caveirao.html 
Faundez, Julio. "Should justice reform projects take non-state justice systems seriously? Perspectives from Latin America." The World Bank Legal Review 2 (2006): 113139.

Fassin, Didier. At the Heart of the State. The Moral World of Institutions (translated by Patrick Brown), London: Pluto Press, 2015.

Fassin, Didier. Enforcing Order. Ethnography of Urban Policing (translated by Rachel Gomme), Cambridge: Polity Press, 2013.

Feltran, G. "Crime e castigo na cidade: os repertórios da justiça e a questão do homicídio nas periferias de São Paulo". Caderno CRH, 23 no. 58 (2010): 59-73. Doi: 10.1590/S0103-49792010000100005

Feltran, G. (2011). Fronteiras de Tensão: Política e Violência nas Periferias de São Paulo. São Paulo: UNESP, 2011.

Foucault, M. Power/knowledge: Selected interviews and other writings, 1972-1977. Pantheon, 1980.

Gambetta, D. Codes of the underworld: How criminals communicate. Princeton: Princeton University Press, 2009.

Gouldner, A. W. (1954). Patterns of industrial bureaucracy. New York: Free Press.

Graeber, D. The utopia of rules: On technology, stupidity, and the secret joys of bureaucracy. Brooklyn: Melville House, 2015.

Gupta. A. "Red Tape: Bureaucracy, Structural Violence, and Poverty in India”. Durham: Duke University Press, 2012.

Hansen, T. B. and Steputtat, F. "Sovereignty Revisited". Annual Review of Anthropology, 35 (2006): 295-315. doi: 10.1146/annurev.anthro.35.081705.123317 
Herzog, L. and Zacka, B. "Fieldwork in Political Theory: Five Arguments for an Ethnographic Sensibility," British Journal of Political Science. (2017): 1-22. doi: $10.1017 / \mathrm{S} 0007123416000703$

Hetherington, K. (2011). Guerrilla auditors: the politics of transparency in neoliberal Paraguay. Durham: Duke University Press, 2011.

Hoag, C. "Dereliction at the South African Department of Home Affairs: Time for the anthropology of bureaucracy." Critique of Anthropology 34, no. 4 (2014): 410-428. doi: $10.1177 / 0308275 \times 14543395$

Holland, A. C. "Forbearance". American Political Science Review, 110 no.2, (2016): 232246. doi: 10.1017/S0003055416000083

Huggins, M.K., Haritos-Fatouros, M and P. G. Zimbardo. Violence workers: Police torturers and murderers reconstruct Brazilian atrocities. Berkeley: University of California Press, 2002.

Hull, M. S. Government of paper: The materiality of bureaucracy in urban Pakistan. Berkeley: University of California Press, 2012a.

Hull, M. S. "Documents and bureaucracy". Annual Review of Anthropology, 41, (2012b): 251-267. doi: 10.1146/annurev.anthro.012809.104953

Jaffe, R. "The hybrid state: Crime and citizenship in urban Jamaica". American Ethnologist, 40 no.4(2013): 734-748. doi: 10.1111/amet.12051

King, R. and Valensia, B. "Power, control, and symbiosis in Brazilian prisons". South Atlantic Quarterly, 113 no.3 (2014): 503-528. doi: 10.1215/00382876-2692164

Lessing, B. "A Hole at the Center of the State: Prison Gangs and the Limits to Punitive Power". Center of Democracy,Development, and the Rule of Law, Stanford University, 2014.

Lipsky, Michael. Street-Level Bureaucracy: The Dilemmas of the Individual in Public Service. Russell Sage Foundation, 1983. 
McFarlane, Colin. "Rethinking informality: Politics, crisis, and the city." Planning Theory \& Practice 13, no. 1 (2012): 89-108.

Mbembe, J. "Necropolitics". Public culture, 15 no.1 (2003): 11-40. doi: 10.1215/08992363$15-1-11$

Mendez, J. E., O'Donnell, G. and Pinheiro, P. The (un)Rule of Law and the Underprivileged in Latin America. Notre Dame: University of Notre Dame Press, 1999.

Merry, Sally Engle. "Legal pluralism." Law \& society review. 22 no. 5 (1988): 869-896. doi: $10.2307 / 3053638$

Moncada, E. Cities, Business, and the Politics of Urban Violence in Latin America. Palo Alto: Stanford University Press, 2016.

Müller, M. M. Public Security in the Negotiated State: Policing in Latin America and Beyond. New York: Palgrave, 2012.

Nordstrom, C. Global outlaws: Crime, money, and power in the contemporary world. Berkley; University of California Press, 2007.

Penglase, B. "States of insecurity: Everyday emergencies, public secrets, and drug trafficker power in a Brazilian favela". PoLAR: Political and Legal Anthropology Review, 32 no. 1 (2009): 47-63. doi: 10.1111/j.1555-2934.2009.01023.x

Pratten, D, and Sen, A. Global Vigilantes: perspectives on justice and violence. London: Hurst Publishers, 2007.

Roy, A. and Al Sayyad, N. Urban Informality: Transnational Perspectives from the Middle East, Latin America, and South Asia. Lanham, MD: Lexington, 2004. 
Roy, A. "Why India cannot plan its cities: Informality, insurgence and the idiom of urbanization". Planning theory, 8 no.1 (2009): 76-87. doi: $10.1177 / 1473095208099299$

Rodgers, D. "The State as a Gang: Conceptualizing the Governmentality of Violence in Contemporary Nicaragua". Critique of Anthropology, 26 no.3 (2006): 315-330. doi: 10.1177/0308275X06066577

Schneider, J., and Schneider, P. T. Reversible destiny: Mafia, antimafia, and the struggle for Palermo. Berkeley: University of California Press, 2003.

Simone, A. City of Potentialities: An Introduction. Theory, Culture \& Society, 33 nos.7-8 (2016): 5-29. doi: 10.1177/0263276416666915

Simone, A. "Pirate towns: reworking social and symbolic infrastructures in Johannesburg and Douala." Urban Studies 43, no. 2 (2006): 357-370.

Skolnick, J. Justice without Trial. New York: Wiley, 1966.

Sluka, J. A. (Ed.). Death squad: The anthropology of state terror. Philadelphia: University of Pennsylvania Press, 2000.

Smith, Christen A. "Strange Fruit: Brazil, necropolitics, and the transnational resonance of torture and death." Souls 15, no. 3 (2013): 177-198.

de Sousa Santos, B. "The law of the oppressed: the construction and reproduction of legality in Pasargada." Law and society review, 12 no.1 (1977): 5-126. doi: 10.2307/3053321

de Sousa Santos, B. "The heterogeneous state and legal pluralism in Mozambique." Law \& Society Review, 40, no. 1 (2006): 39-76. doi: 10.1111/j.1540-5893.2006.00258.x

Sudnow, D. "Normal Crimes: Sociological Features of the Penal Code in a Public Defender Office.” Social Problems, 12, no. 3 (1965), 255-276. 
Tilly, C.. "War Making and State Making as Organized Crime". Chap. 5 in Bringing the State Back In, edited by Evans, Peter, Dietrich Rueschemeyer and Theda Skocpol, 169186. Cambridge: Cambridge University Press, 1985.

Townley, B. Reason's neglect: rationality and organizing. Oxford: Oxford University Press, 2008.

Weber, M. From Max Weber; Essays in Sociology. Translated, Edited and With an Introd. by HH Gerth and C. Wright Mills. London: Oxford University Press, 1946.

Wedeen, L. "Reflections on Ethnographic Work in Political Science." Annual Review of Political Science, 13 (2010), 255-72. Doi:

10.1146/annurev.polisci.11.052706.123951

Wedeen, Lisa. Ambiguities of Domination: Politics, Rhetoric, and Symbols in Contemporary Syria. Chicago: University of Chicago Press, 2015.

Notes

1. Lipsky, Street Level Bureaucrats.

2. Huggins, Haritos-Fatouro and Zimbardo, Violence Workers.

3. Hansen and Stepputat, Sovereignty Revisited; Rodgers, The State as a Gang; Pratten and Sen, Global Vigilantes.

4. Davis, New Imagined Communities.

5. Foucault, Power/Knowledge, 109.

6. Brinks, Judicial Response to Police Violence; Biondi, Sharing this Walk; Biderman, de Lima and Pinho de Mello, Pax Monopolista; Denyer Willis, The Killing Consensus.

7. Schneider and Schneider, Reversible Destiny, 34.

8. Denyer Willis, The Killing Consensus; Before the Body Count; Antagonistic Authorities; The Potter's Field.

9. Denyer Willis, The Killing Consensus.

10. Weber, From Max Weber.

11. Weber, From Max Weber 196-7.

12. Townley, Reason's Neglect, 65.

13. Centeno, Blood and Debt; Arias and Goldstein, Violent Democracies; Moncada, Cities Business and Politics; Arias, Criminal Enterprises; Barnes, Criminal Politics. 
14. Arias, Drugs and Democracy; Müller, Public Security in the Negotiated State; Jaffe, The Hybrid State.

15. Holland, Forebearance.

16. Gouldner, Patterns of Industrial Bureaucracy; Skolnik, Justice Without Trial; Hull, Government of Paper.

17. Wedeen, Reflection on Ethnographic Work.

18. Hetherington, Guerrilla Auditors; Auyero, Patients of the State; Gupta, Red Tape; Hull, Government of Paper and Documents and Bureaucracy; Anand, Leaky States.

19. Hoag, Dereliction at Home Affairs; Graeber, Utopia of Rules

20. Chatterjee, The Impunity Effect.

21. Sousa Santos, The Heterogeneous State; Merry, Legal Pluralism; Brunnegger and Faulk, A Sense of Justice.

22. Faundez; Justice Reforms and Non-State Justice; Fassin, Enforcing Order and At the Heart of the State.

23. Herzog and Zacka, Fieldwork in Political Theory.

24. Roy and Allsayyad, Urban Informality; Roy, Why India Cannot Plan; Macfarlane, Rethinking Informality; Simone, Pirate Towns.

25. Mbembe, Necropolitics.

26. Wedeen, Ambiguities of Domination.

27. Amengual, Pathways to Enforcement and Politicized Enforcement in Argentina.

28. Coslovsky, Flying under the Radar and Beyond Bureaucracy.

29. Amengual, Complementary Labor Regulation.

30. Penglase, Everyday Emergencies.

31. Arias, Drugs and Democracy.

32. Schneider and Schneider, Reversible Destiny, 34.

33. Within Brazilian police agencies there are many hierarchies written through by external conditions and status prerequisites. The delegado is a 'chief detective' who oversees a team of workers, each working in their own division of labour. The delegado is a patron. When she or he is moved to another agency or organisational location, the team often moves too. Trust, then, tends to circle around these kinds of work and social forms, where members of the team benefits or lose relative to their leader. Delegados must have a university degree. The same basic conditions are true of the officers in the 'beat' cop Military Police, who follow, though, a military hierarchy and system of discipline.

34. Denyer Willis, The Salvific Sensorium.

35. Estadão, Calabar.

36. Fantti, Policia Cobrava Propina.

37. The Military Police are Brazil's 'beat cops'. They are organized in a Military hierarchy and according to the Brazilian constitution are a reserve force of the national military.

38. Smith, Strange Fruit; Alves, Neither Humans nor Rights.

39. Mendez, O'Donnell and Pinheiro, The UnRule of Law.

$40.76 \%$ of files that noted the race of the victim note a black victim. Data from the Forum Brasileira de Segurança Pública.

41. Bueno and Denyer Willis, The Exceptional Prison

42. Sudnow, Normal Crimes, 259.

43. I present this vignette also in a recent book, The Killing Consensus: Police, Organised Crime and the Regulation of Life and Death in Urban Brazil.

44. Dal Bo, Dal Bo and Di Tella, Plata o Plomo. 
45. Tilly, State-Making as Organized Crime. 